The final publication is available at Springer via http://dx.doi.org/10.1007/s10991-017-9193-7.

\title{
Truth and Consequences: Law, Myth and Metaphor in American Indian Contested Adoption
}

The overarching story of Pigs in Heaven is a fleshed-out case history in an Indian child custody proceeding. Kingsolver gives voice, through individual voices, to both sides of the thorny "best interests of the child" and "who gets to determine them" questions." (Metter Lorillard: 2005: 12).

\section{Introduction}

What are the consequences of the way in which myth and metaphor intertwine with legal interpretation? What happens to an issue that challenges the 'truth' of a myth, particularly a myth that is at the heart of national identity? All of these questions are at play in this article's discussion of the role of myth, metaphor and law in the contested adoption of an American Indian child. Behind their workings are issues of identity which go to the heart of the way in which a state sees and constructs itself.

This article compares the operation of myth and metaphor in a novel and a United States Supreme Court case, both of which deal with the contested adoption of an indigenous Cherokee Nation child. In each, the Cherokee Nation asserted its interest in the child's adoption, opposing the adoption by the prospective white adopter. The role of the Indian Child Welfare Act (ICWA), federal legislation that controls the foster care and adoption of American Indian children, and the way in which it challenges widely accepted myth and metaphor, and with what result, is discussed. Legal interpretation may be presumed to be usually consistent with the national myth. But there are instances where the interpretation may be counter to the myth. How and when these occur, and with what result are also important for understanding the role of myth and metaphor in the operation of law.

The silent operation of myth and metaphor and their effect on the operation of law are brought to the fore in this discussion of the contested adoption of an American Indian child. There are many unresolved issues around the location of the American Indian in law, what their relationship should be to the federal government and to the United States Constitution. The role of myth and metaphor on the interpretation of law, and efforts to locate American Indians within 
the law are highlighted through a comparative discussion of a novel and a United States Supreme Court case that both involve issues of a contested adoption of an American Indian child. Perhaps not all legal issues are susceptible in the same way to the influence of myth and metaphor. Those that are most susceptible, this article argues are those issue that go to the heart of national identity as constructed within a national founding myth.

The founding myth helps to establish the foundation for a particular form of nation. The United States has a Jacobin form of statehood-one where the orientation and identity is to the state and not to sub-groups within the state. This basis for a state results in hostility to sub-group identifies (Bornman 2006) — and is thus hostile to tribal (sub-group) identity as a risk to the foundation of the state itself. (Sargent and Melling 2012). The Jacobin form of statehood can be contrasted with the syncretistic form that ' involves policies of multiculturalism that guarantee the cultural rights of ethnic or other minorities’. (Bornman 2006: 386). The Indian Child Welfare Act can be seen as a syncretistic rather than Jacobin piece of legislation.

The United States has as its founding myth one that supports this Jacobin form of statehood-the myth of Manifest Destiny. As discussed further in this article, it calls upon the formation of the United States as a Christian nation from the Atlantic to the Pacific coast as part of a divine will and destiny.

The origins of Manifest Destiny are from a much larger set of myths. Manifest Destiny is specific to the United States, but calls upon divine will for the European Christian presence in the New World have a much broader dictate. Noted American Indian scholar Professor Robert Williams, Jr, comments

law, regarded by the West as its most respected and cherished instrument of civilization, was also the West's most vital and effective instrument of empire during its genocidal conquest and colonization of the non-Western peoples of the New World, the American Indians. (Williams 1990: 6). 
Law operated to help deliver the vision of a larger mandate, again, as described by Williams:

...the Western colonizing nations of Europe and the derivative settler-colonized states...have been sustained by a central idea: the West's religion, civilization and knowledge are superior to the religions, civilizations, and knowledge of non-Western peoples. This superiority, in turn, is the redemptive source of the West's presumed mandate to impose its vision of truth... (Williams 1990: 6).

In other words, replacing American Indian culture with European-based Christian culture and society was not only ordained by a Christian God, but it was to the benefit of those who were so changed. This idea of a redemptive quality can be seen in arguments that assimilation of American Indian children to white culture was in their best interests, as discussed within this paper.

Manifest Destiny is part of this mandate, and it takes its place as part of the discourse that justified the vanquishing of American Indians. Wilson's comments reveal law as a very potent tool in achieving this endeavour. Manifest Destiny has transgressed discourse to take its place as the founding myth of the United States, giving it a very powerful place indeed in the efforts to if not eradicate to assimilate American Indians-a myth that continues in operation to this very day. ICWA serves to challenge both the myth and the mandate, raising an issue of identity, which is magnified in the considerations of the adoption of an Indian child by a non-Indian family. The implications for American Indian children, and the future operation of ICWA, now strengthened by binding federal regulations that came into force on December 12, 2016 are highlighted in this discussion.

The article proceeds as follows. The first section examines the operation of myth and metaphor in the establishment of Manifest Destiny as the founding myth of the United States, and further, in the metaphor of the vanished American Indian. The second section discusses the Indian Child Welfare Act and the ways in which some of its provisions are in contradiction of the Jacobin basis of the United States and of the Manifest Destiny myth. As Atwood (2002: 599) notes'...ICWA itself can be seen as a mandate for cultural pluralism...' This sort of cultural pluralism runs counter to the Jacobin aims of Manifest Destiny. 
The third section looks at the way in which issues of American Indian identity are dealt with in the contested adoption of an Indian child. It does so through a comparison of the novel, Pigs in Heaven, and of the same issue in a 2013 United States Supreme Court decision, Adoptive Couple $v$ Baby Girl. The differing ways in which American Indian identity is discussed in each reveal the conflict between Manifest Destiny and ICWA. This raises then further questions of the consequences of a legal interpretation that runs counter to the national founding myth. These are discussed in the concluding section of this article.

\section{Manifest Destiny: The Founding Myth of the United States}

It might come as a surprise to many Americans that there are still living American Indians. Such is the reach of the founding myth of Manifest Destiny and its effects. Yet, the ideal of having achieved Manifest Destiny is dependent upon the metaphor of American Indians as 'relics of the past' (Anaya 2012: para 9). Former Special Rapporteur of the Rights of Indigenous Peoples, James Anaya, details in his 2012 report on his visit to the United States that the metaphor of the American Indian as vanished and vanquished 'obscure[s] understanding of the reality of Native Americans today and instead help to keep alive racially discriminatory attitudes.' (Anaya 2012: para 9). But the view of the American Indian that is perpetuated by this metaphor is inaccurate, again as Anaya notes, 'Beyond the stereotypes, one readily sees vibrant indigenous communities, both in reservation and other areas, including urban areas...” (Anaya 2012: para 10, emphasis added).

A founding myth is a narrative of the creation of a nation-state. It explains how the nation-state was formed, what its purpose or calling is, and serves as a central focus point for identity and the cohesiveness of a large collective group. The effects of a founding myth are so deeply ingrained in the way in which a society operates that it may not even be overtly recognized as having an existence or effect. In other words, a founding myth can exist and exert influence without explicit acknowledgement. Thus, national myths have a very powerful, if sometimes seemingly subtle, influence on national identity, as well as outlining expectations and justifications for behavior. As Coles explains, these “...narratives, sacred symbols and ideals...undergird a 
country's self-definition, explain why and how a society came to be, justify why its members do what they do...” (Coles 2002: 403).

Leading scholar Anthony D Smith, in his seminal work, Myths and Memories of the Nation, explains that there are four broad categories of such myths.

The first is imperial-dynastic', with a 'myth of election... attached to the ruling house and dynasty, form which the community tends to take its main symbols and culture, and with which it is always associated.' The second is 'communal- demotic', where 'the community has usually been conquered and is struggling to preserve its former way of life, claiming that its members are the original inhabitants...' (Smith 1990: 136). This can be associated with the American Indian groups in the United States, although this has little discussion within the Pigs in Heaven. Rather, another myth takes the foreground, suggesting that nation-based myths are not the only ones which are significant for binding a group together. The Pigs in Heaven fable is one which is about maintaining bonds, and this can be seen as another way in which groups find a common core that links them together. In this respect, the myths that Smith identifies are potentially not the only one which can provide group cohesion.

The third pattern that Smith(1990: 137) identifies is that of 'diaspora-restoration' where a group returns to its 'old homeland', which return has become 'the precondition of collective redemption.'

The national founding myth of the United States, Manifest Destiny is representative of what Smith(1990: 137) identifies as the 'emigrant-colonist' national myth. Smith(1990: 137) explains that 'the immigrants and their descendants...regard[] themselves as chosen by God for a providential destiny that will abolish the old order and inaugurate a new society.'

Simply put, Manifest Destiny is a myth that 'God led people (white Europeans) to America to found a new and superior or exceptional social order that would be the light unto all nations.' (Cole 2002: 406). Manifest Destiny was used as a basis to justify a coast to coast expansion of the United States in the $19^{\text {th }}$ century. (Pratt 1927). Since then however, the myth has adapted to 
changing circumstances in the United States and remains as relevant and powerful a founding myth today as it was in the $19^{\text {th }}$ century (Coles 2002).

Manifest Destiny operates to help support a state based on Jacobin principles of primary identity to the state, rather than to sub groups. A point of contestation in assimilation is that of identitywith whom will an individual or a group identify? The context of Manifest Destiny as the bedrock of a Jacobin state makes identity a defining feature of its operation.

Identity is at the heart of a Jacobin-based state, and thus is also at the heart of what Manifest Destiny needs to achieve through its assimilationist efforts.

The maintenance of identification as an Indian is at odds with the aims of a Jacobin state, and thus is something that Manifest Destiny operates to eradicate. Continued identification with a sub-group, of being part of an American Indian tribe, can be construed as a threat to the state (Sargent and Melling). The assimilationist polices that were part of the Manifest Destiny myth used removal of American Indian children from their indigenous group and culture as one means of achieving this aim. Wallace Adams (1995:59; see also Anaya 2012: para 45) explains the philosophy behind the assimilationist practices of Indian child removal:

...the idea was gaining force that Indian children needed to be removed from their tribal homes... Only by attending boarding school, policy makers were now convinced, could Indian youth, stripped bare of their tribal heritage, take to heart the inspiring lessons of white civilization.

This official policy of removal that was put to an end by the Indian Child Welfare Act in 1978.

\section{Law: The Indian Child Welfare Act}


For several decades, the United States government pursued a policy of removing American Indian children from their families and communities. The removal was in various guises. One was the use of off-reservation boarding schools. Another was the placement of children for adoption in white, non-American Indian homes. These removal tactics were designed to break the ties that children had to their identity as American Indians, and to their language, culture and religion. While it may seem curious in hindsight, these were not ill-intended programs. They were undertaken with the genuine belief that they were of benefit to the American Indian children that they effected. One example of this is the Indian Adoption Project run by the Child Welfare League of America, which viewed placement of children away from their tribal community as advantageous for the child. (Indian Adoption Project).

The policy followed to ensure American Indian assimilation are detailed in comments by Graham (1998: 20-21) highlighting the role of child removal in achieving assimilation:

By 1953 Congress had officially adopted a new policy of rapid and coercive assimilation...The assimilation practices of this era were aimed at every facet of Indian life — from the land base, to the community structure, to the individual child....

A 1944 congressional report condemned the use of community school sand encouraged a return to off-reservation boarding schools, where the children could "progress" much quicker in the "white man's way of life."

In 1978, Congress passed the Indian Child Welfare Act (ICWA). ICWA put an end to decades of child removal for the purpose of assimilation as the official government policy towards Indian children. But the decades of involuntary removal had taken their toll with the removal of a significant portion of American Indian children : ' ...approximately 25-35 percent of all Indian children are separated from their families and placed in foster homes, adoptive homes or institutions” (Legislative History, House Report 95-1386, Indian Child Welfare Act of 1978, 7531). 
The Indian Child Welfare Act protects children from unwarranted and involuntary removal from their families and tribes. It does so in several ways.

When a child is to be placed in foster care or for adoption, each have a hierarchical placement preference list. For foster care this is firstly with 'a member of the Indian child's extended family'(ICWA, sec 1915(b)(i)) (a tribal definition of 'extended family' is to be used if one exists, otherwise the ICWA definition of 'extended famil'y is the default position)( ICWA, sec 1903(2)); 'a foster home licensed, approved, or specified by the Indian child's tribe,( ICWA, sec 1915( )(ii)); thirdly, 'an Indian foster home licensed or approved by an Indian tribe or operated by an Indian organization(ICWA, sec 1915(b)(iii )); fourthly, 'an institution for children approved by and Indian tribe or operated by an Indian organization which has a program suitable to meet the Indian child's needs.'(ICWA, sec 1915(b)(iv).).

Likewise, there is a hierarchical list of preferences for adoption placement: 'with a member of the child's extended family' (ICWA, sec 1915 (a) (1)); then, 'other members of the Indian child's tribe'(ICWA, sec 1915(a)(2)); and lastly, 'other Indian families.'(ICWA, sec 1915 (a)(3)).

The Act also notes that tribes can establish a different order of preference by 'tribal resolution'which would then be followed in place of the statutory preferences for both foster care and adoptive placements. (ICWA, sec 1915(c)).

Notably, binding regulation have been issued that direct courts on the implementation of ICWA, trying to take away the ability of courts to evade its application. The binding regulations issued in June 2016, taking effect in December 2016 (Federal Register, Vol 81, No 114, June 14, 2016 38778) stress the hierarchical nature of the placement preferences. The regulations state that the preferences for adoptive placement, foster care and pre-adoptive placements respectively 'must be given in descending order, as listed below...” (Federal Register, Vol 81 No 114, Tuesday, June 14, 2016, Rules and Regulations secs 23.130(a) and 23.131(b)).

Judicial resistance to the application of ICWA and its grants of tribal authority were immediate. The judicially created doctrine of the 'Existing Indian Family' (EIF) was used to circumvent the use of ICWA Under this doctrine, judges would determine whether or not to apply ICWA. Using whatever standard the judge wished to, a decision was made as to whether the child in question 
had sufficient (as deemed within the eyes of the judge) ties to their Indian culture. This is contrary to the plain language of ICWA. ICWA applies to a child that meets the statutory definition of an "Indian child", and there is no role provided to courts to determine the nature of cultural ties that the child might have. (Atwood 2002).

The 2016 regulations make a definitive statement about EIF, noting that 'the state court may not consider factors such as the participation of the parents or Indian child in Tribal cultural, social, religious, or political activities...' as a means to circumvent the application of ICWA. (Federal Register, Vol 81 No 114, Tuesday, June 14, 2016, Rules and Regulations sec 23.103 (4) c)).

\section{Contested Adoption in Fiction and US Supreme Court Decision}

Pigs in Heaven is a story by Barbara Kingsolver that is a sequel to The Bean Trees. The Bean Trees details the adoption of an abandoned child. Pigs in Heaven is the author's return to the story, as she felt she had not given sufficient attention to the American Indian point of view, and in particular, on the reasons for and effect of the Indian Child Welfare Act. Kingsolver explains in her opening acknowledgements that the book explores the "letter and spirit of the Indian Child Welfare Act.” (Kingsolver 2013: Acknowledgements). Pigs in Heaven is about a contested adoption - where the abandoned child turns out to be a member of the Cherokee Nation, with an extended family and tribe who want her to return and be aware of and part of her Cherokee heritage, while her adoptive mother, who is white, is afraid of losing the child who she regards as her daughter.

But the book is also about a myth - the myth from which the title is derived. This myth can be seen as a commentary about the effects of Manifest Destiny on the modern day Cherokee Nation, of the importance of clinging onto family and tribal ties even when vast forces operate to separate individuals from these.

The book also reflects upon what was then the only case on ICWA to be heard by the US Supreme Court. That case, Mississippi Band of Choctaw Indians v Holyfield (490 U.S. 30 
(1989)) upheld the rights of the tribe in a contested adoption. The tribe was found to have exclusive jurisdiction over the adoption of a child who had been born to tribal members domiciled on the reservation and who had subsequently been adopted by a white non-tribal family. In discussing the case, Cherokee Nation and lawyer character Annawake Fourkiller says of the decision and its reflection on ICWA

It shows the spirit of the law. The Indian Child Welfare Act is supposed to protect the interests of the Indian community in keeping its children. (Kingsolver 2013: 64).

The interests of Indian groups in keeping their children and in maintaining ties with them, even against great odds, is embodied in the Pigs in Heaven myth within the novel, standing in contrast with the continual efforts at removal.

\section{The Counter-Vailing Myth}

The novel itself engages with a myth, which can be seen as a counter-narrative to the metaphors that are deployed in support of the myth of Manifest Destiny, and to the Manifest Destiny myth itself. The title of the novel, Pigs in Heaven, takes its name from the myth, which is woven and re-woven into the story of the novel. The Pigs in Heaven fable is told as one where six children are turned into stars after disobeying their mother.

What meaning the fable is to be given depends on what point in the novel it appears-reflecting the malleable nature of myth. As Annawake Fourkiller explains, '"Myths are myths. They're good if they work for you, and bad if they don't."' while also acknowledging, '”There's a lot of different versions of all the stories, according to what mood you're in.”' (Kingsolver 2013: 88).

However, there is a dispute between the number of stars that are in the Pleiades formation referenced in this myth-- whether six according to the Cherokee fable, or seven, as the white characters in the novel suggest. In a second telling in the novel, the fable stands for something other than a cautionary tale to misbehaved children. Instead, as the tale is re-told by Annewake Fourkiller, she explains the difference in numbers, when explaining that "“The spirits put them up there to stay. To remind parents always to love their kids no matter what, I guess, and cut them a little slack."' In acknowledging that there might be seven stars rather than six, Annawake 
says, “"The Six Pigs in Heaven, and the one mother who wouldn’t let go.”' (Kingsolver 2013: 314).

In this way, the Pigs in Heaven myth can be seen as a counter-narrative to the removal that is deeply embedded in Manifest Destiny — and of the efforts of parents and tribes to retain their contacts with children, even those, and perhaps especially those, who have been taken away.

This also underscores the issue of identity. Identity is at the heart of a Jacobin-based state and is also at the heart of what is achieved through the assimilationist aims of Manifest Destiny. The identity of children would be changed from Indian to that of a non-Indian. Adoption also performs a change of identity, and when an Indian child is adopted into a non-Indian family, the identity then arguably shifts away from the American Indian community. This is seen in the adoption efforts discussed earlier in this article. So it is that a contested adoption of an American Indian child by a non-Indian family has at its core the issue of identity. Identity becomes an important battleground because of the place it has in the foundational basis of the United States, and its national founding myth of Manifest Destiny. It should be of little surprise then that in both fiction and reality, the use of ICWA in a contested adoption of an American Indian child becomes a contest over identity. Atwood (2002) comments that ICWA has cast a very broad definition for who falls within the ambit of the law as an 'Indian child'.

The 2013 US Supreme Court decision, Adoptive Couple v Baby Girl (570 U.S. (2013)) has facts which are an eerie mirroring of the early novel. Each deals with the contested adoption of a Cherokee Nation child by a non-Indian family. The novel neatly solves the dilemma by allowing an expansion of the family to allow the tribe, the would-be adopter, and the child's extended family to form a harmonious home for the child. The opposite conclusion was reached in the US Supreme Court case, which ultimately operated to permit the adoption of the child by the nonIndian family.

In both the novel and the court decision, the issue of identity—of who is a Cherokee, and who decides, become a feature of discussion. 
The Cherokee Nation has also taken a very inclusive view as to who could be a member, as illustrated by a discussion in the novel:

...We're not into racial purity, as you've probably noticed. It's a funny thing about us eastern tribes, we've been mixed blood from way back, even a lot of our holy people and our historical leaders... It’s no stigma at all. (Kingsolver 2013: 278).

This view of a fluid formation of identity, without a fixed mandate as to how a person is to identify is expressed at various points in the novel.

It don't have to be more than a drop. We're all so watered down here, anyway. Did you see them blond kids at the stomp dance, the Threadgills? They're signed up. Roy Booth over here at the gas station, he's enrolled, and he's not more than about one twohundredth. And his kids are. But his wife, she's a quarter, but she's real Methodist. So she don't want to sign up. It's no big thing. Being Cherokee is more or less a mind-set. (Kingsolver 2013: 275).

The Cherokee Nation did not adhere to the idea of "blood quantum" in determining who was a member of the tribe. The idea that it should be up to the tribe, and not to non-tribal society or laws, the idea of tribal membership as up to the rules of the particular tribe are also the subject of comment in Pigs in Heaven :

But generally there's no reason why enrollment should be restricted to full bloods, or half-, or wherever you'd want to make a cutoff. Anybody who lives our way of life should have the chance to belong to the tribe. I sure don't think outsiders should tell us who can be enrolled. (Kingsolver 2013: 278-279, emphasis in the original).

This stands in contrast to the more rigid view of identity and tribal belonging that is presented in the 2013 Supreme Court decision. In the opening lines of Adoptive Couple v Baby Girl, the Court declaims the ties that the child has to the Cherokee Nation, based on a low percentage of blood quantum. It is also the commentary of an outsider as to who should be a member of the Cherokee Nation: 
This case is about a little girl (Baby Girl) who is classified as an Indian because she is $1.2 \%(3 / 256)$ Cherokee. Because Baby Girl is classified in this way, the South Carolina Supreme Court held that certain provisions of the federal Indian Child Welfare Act of 1978 required her to be taken, at the age of 27 months, from the only parents she had ever known and handed over to her biological father, who had attempted to relinquish his parental rights and who had no prior contact with the child. (Justice Alito 2013: Majority Opinion, Adoptive Couple v Baby Girl)

This statement from the US Supreme Court about why the Indian Child Welfare Act applies, and why the child was seen to meet the statutory definitions of being 'an Indian child' under ICWA are wholly inaccurate. It completely misstates the premise by which a child is subject to the requirements of the Indian Child Welfare Act. The inflammatory nature of this commentary and its prominence in the opening part of the opinion speaks volumes of the unease with which the 'Indian subject' who is part of a tribe is regarded by the rest of American society. It represents the heart of the dilemma that arises with the collision issues of identity in the workings of law, myth and metaphor.

Does the majority opinion statement reveal a fundamentally flawed and erroneous understanding of the basis upon which the Act is to apply to a child? At first blush, it does appear that the Court does not understand the threshold for the application of ICWA. Later reading in the opinion reveals however that there is a detailed knowledge of the way in which the Act is to apply, making it difficult to believe the Court fails to understand the definition of 'Indian child' within the Act.

What then is the purpose of this repeated statement about fractions of blood? It is unlikely to be deliberate error, and as discussed above, it is unlikely to be an error in understanding this portion of the Act. Rather the Court is expressing its dismay of an identity with a tribal group, in a way that is determined by the tribe. Bearing in mind the mandate that Williams has identified for the role of law and legal discourse in achieving the aims of Manifest Destiny, this statement by the Court is not a mistake, even though it is a misstatement of law. 
The Court majority decision clearly comes down on the side of Manifest Destiny. Perhaps the question to be asked is: given the power of the founding myth, could it be expected that the Court could have done otherwise?

It is true that another decision, Mississippi Band of Choctaw Indians v Holyfield ( 490 U.S. 30 (1989)), made a decision that was in favor of a tribe retaining its tie to children adopted outside of the tribe-and the Supreme Court went so far as to reverse the adoption. Again, there is commentary from Pigs in Heaven:

In the case of Mississippi Band of Choctaw versus Holyfield, the mother voluntarily gave her children to the white couple. The children had never even lived on the reservation. And the Supreme Court still voided that adoption. (Kingsolver 2013: 64, emphasis in original).

The 1989 Supreme Court case upheld a child's identity as an Indian, and the interest that the tribe had in that child, in a contested adoption. But this view of identity and tribal interest seems to be contradicted by the decision issued in 2013 .

This is representative of the fluctuations of federal policy towards American Indians, of a deeply held ambivalence about the location of American Indians in law. The truth is that American Indians remain as groups with distinct identities as Indians and are not wholly assimilated into an identity devoid of tribal connections. Law and legal discourse then struggle to grapple with this reality that is at odds with the myths and metaphors communicated. Just as it was a mistake to view the Mississippi Band of Choctaw Indians as setting forth a judicial embrace of ICWA and a changed location of the American Indian subject within the law altering the dictates of Manifest Destiny, so would it be a mistake to assume that the new binding federal regulations will necessarily counter the effects of Manifest Destiny, or that they can do so without a fight.

There is a difficulty in transcending the powerful influence of myth and metaphor, even where, in a story such as Pigs in Heaven, it is the aim of the author to do that very thing. One of the criticisms of literature in discussing American Indians is who should write about them. In this, this issue parallels that of jurisdiction — who should speak, who is entitled to make decisionsthe state courts or the tribal courts. There is a tension that runs across both—who should speak 
and make decisions about American Indians? Who has sufficient insight? What is required to have the authority, the authenticity to speak? This is noted in the opening quote to this article.

The continued existence of American Indian “voice” is at odds with Manifest Destiny. Manifest Destiny success is predicated upon the assimilation and erasure of American Indians, and any remnant of American Indian voice can be seen as a threat to the idea that there is a credible core to Manifest Destiny. American Indian voice raises a serious challenge to the myth-threatening to expose it as unfulfilled and thus to threaten the bedrock of the American society identity. Thus, silencing of American Indian voice is key to achieving Manifest Destiny. This is recognised in comments by Williams (1990: 327):

Denying that voice [of tribal peoples], however, would most assuredly assist the efforts of those in power who seek the silent liquidation of colonized tribal peoples.

The issue of "voice" is an important part of considering the effects of myth and metaphor within the application of law. Not only is it important to consider what story is being told, it is important to consider who is able to speak, to tell the story. The silence of the American Indian voice would speak to the effects of Manifest Destiny in achieving the aim of a Jacobin based state. The continued existence of this voice suggests that the American Indian continues to exist, if not to thrive, against the forces exerted by Manifest Destiny.

Pigs in Heaven is an effort to present an American Indian viewpoint on the importance of the Indian Child Welfare Act. But does it? Outsiders trying to tell the story of American Indians from the American Indian viewpoint is often seen as problematic, because of the inescapability of the use of stereotyping myth and metaphor. Bayers (2007: 36) explains this as a problem in all representations in popular films, reinforcing the idea of the vanished American Indian, and thus leaving no room in the imagination for the somewhat assimilated Indian of today:

...films such as Dances with Wolves (1991), the Last of the Mohicans (1992) and Geronimo: An American Legend (1993), reengaged the myth of the frontier in an attempt to show sympathy for Natives; but they all still engage in tired stereotypes and mythologize Indians as not-so-complex heroes, implicitly suggesting that Indians died out a long time ago and thus exist only in the past. 
While on one hand Kingsolver's novel is lauded for its efforts to tell that story of the Indian Child Welfare Act from a viewpoint that acknowledges the tribal concerns and tribal position, on the other hand it is criticized for its efforts to do this very thing:

Although well-intentioned, Kingsolver's novel runs into representational problems in regard to her portrayal of Natives, despite her efforts to challenge these very representations overtly. Granted, the novel takes great pains to frame the Cherokee removal within the context of genocide, and it highlights the continued injustices faced by contemporary Native peoples - particularly illegal adoptions of Native children by non-Native parents—but in the end it still romanticizes and idealizes Natives, reinscribing the cultural hegemony of Euroamerican imaginings of Native American peoples.(Bayers 2007: 37)

The happy ending that is offered in the novel is almost too neatly packaged up in a way that resolves all of the competing tensions pleasantly and completely, with the child now the bridge between two families, rather than being part of one and closed off from another. Certainly the happy ending of the novel does not portend the real life ending of the US Supreme Court case, which resulted in the diminution of ICWA, and the removal of the child from her birth father to be adopted by a non-tribal family. In the ' cultural hegemony of Euroamerican imaginings' there is a happy ending - and ICWA is not contested in the way that it relentlessly has been in real life.

There are dissatisfactions among critics of Barbara Kingsolver's telling of the story of the Indian Child Welfare Act, many of which centre on who should be telling the story of American Indians. While this article does not enter into the debate over whether non-Indians should be telling the stories of (and indeed, interpreting the myths of) American Indians, it is worth noting the debate in the context of this paper. Who tells the story is redolent of what meaning it is given, and in what context—as shown in the shift of meaning assigned to the Pigs in Heaven fable itself within the novel. The storyteller controls the context and the meaning-and so the power and place that the myth itself will occupy. The novel provides a happy ending that is one that seamlessly unites the child's white and Cherokee families, with the convenient location of Cherokee heritage in the white family, and a romance that blends the two competing families. Whether an American Indian telling this sort of story would come up with such a solution is an open question. Whether Kingsolver's telling of this story is a misappropriation of the story is another question — who should tell the story of the loss of generations and the continuing into the present day question over who is an Indian and who decides? 
Thus, the novel itself recognizes the power of not only a myth, but of who tells the myth, and of how the meaning of a myth can shift dependent upon its context. This begs the question that is implicit in the conflict of the novel and its happy ending with the Supreme Court decision- what does it mean to be an Indian, who is an Indian, who decides, and what voice is or should be given to the narrative? The narrative of the Supreme Court decision is to drown out any Indian voice, to reclaim the right to be the story teller. Who the story teller is or should be is given more ambiguous ground in Pigs in Heaven, but in so doing, the power of the story and of the story teller is acknowledged. Perhaps this is the most important lesson that can be gleaned from a comparison of the novel and the Supreme Court decision.

Many different accounts have been offered by reviewers about the story that is found in Pigs in Heaven. It is, as in any complex work of fiction, a story with many facets, sub-plots, imagery and resolution that can be drawn upon. But the view given by Metteer Lorillard is one that suggests that Manifest Destiny may even guide the reader in a preference to an ending in which the child's ties to her adoptive white mother are not entirely cast aside-if this is the story which is familiar to the reader:

The problem, however, is that the choice of which story to privilege is most often determined by the story that comes closest to the experience of the listener.(Metteer Lorillard 2005: 256).

ICWA tries to repair the actions which were part of assimilation, through its involvement of the tribe, and recognition of cultural practices of the tribe. However, the 2013 Supreme Court decision resists the restorative aims of ICWA. That is because the restorative aims repudiate the legitimacy of Manifest Destiny, and its means to achieve its objectives. For those who subscribe to the founding myth of Manifest Destiny, the existence of ICWA is more than a troublesome thorn in the side. It is a direct contradiction of founding myth. This view of ICWA in relation to the founding myth goes a long way towards explaining the antipathy that the legislation has engendered.

Although Kingsolver has in some ways attempted to demonstrate that the myth of Manifest Destiny is not the narrative through which the story should be told, some critics argue that she is unable to resolve other myths and metaphors, that of a romanticizing of American Indians. This 
simply creates more distancing, according to Schultermandl (2006:225)where Kingsolver's 'idealization and exoticization of the Cherokee Nation, for instance, contributes to the further differentiation of Native American tribes as cultural “other.”,

The acceptance of American Indians within the wider embrace of American society- of being included - is an elusive pursuit — and demonstrates the strength and the prevalence of myth and metaphor.

And yet, there is a place for literature to continue to try to dispel the myths and metaphors. Indeed, Bayers (2007) says that this must be done to try to overcome the effects of myth and metaphor, to come face to face with the truth and its consequence that can be so comfortably and conveniently hidden by these. It is perhaps here that Pigs in Heaven has a most valuable role to play, whatever shortcomings its critics may point out. Pigs in Heaven is able to help its readers confront the different views about ICWA, and to understand the reasons for the hostility that it faces, even perhaps to reach a deeper understanding of decision rendered by the Supreme Court. Metteer Lorillard (2005:263) explains:

Kingsolver helps her readers with this tasks by presenting several internal stories illustrating the differing world-views that account for problems underlying application of the Act....Kingsolver asks the reader to peek behind those doors, to compare realities, and then to open the door into each other's culture.

A comparison of Pigs in Heaven and Adoptive Couple v Baby Girl points out the similarities and difference that exist in fiction and in real life. When confronted with the same issue-the contested adoption of a Cherokee Nation child by a non-Cherokee family, vastly different solutions are reached. In the novel, a happy ending is crafted that allows the child to forge bonds with both her Cherokee and non-Cherokee family. In the court case, the child's Cherokee bonds do not allow the same conclusion to be reached. ICWA, rather than the hero of the story, becomes its villain, and the Supreme Court diminishes the importance that ICWA has in the lives of children subjected to contested adoptions. 
Myth and metaphor have a powerful hold of the national imagination and identity of the United States, especially in the form of its national founding myth of Manifest Destiny. As Williams has explained there is a particular directive within the intertwinement of legal discourse, myth and metaphor. Fluctuation in federal policy, as now seen with the binding federal regulations on ICWA, do not necessarily reflect a repudiation of the Manifest Destiny myth. Rather, these might be seen as the latest effort in a continued struggle within myth, metaphor and legal discourse to locate the American Indian. When efforts at assimilation are discarded, as with ICWA, the question of where to locate the American Indian within Manifest Destiny and a Jacobin state remain. Just as the Existing Indian Family doctrine was created as a backlash against ICWA, so might there be a backlash against the federal regulations. It could be said that the effect of the Existing Indian Family doctrine was to make ICWA fit within the boundaries of Manifest Destiny and its legal discourse. And so a similar effort might be expected against the binding regulations, for at least as long as legal discourse continues to advance the myth of Manifest Destiny.

\section{References}

Adams, David Wallace. 1995. Education for Extinction: American Indians and the Boarding School Experience 1875-1928. Lawrence: University of Kansas Press.

Adoptive Couple v Baby Girl. 570 U.S. __ (2013).

Atwood, Barbara. 2002. Flashpoints Under the Indian Child Welfare Act: Toward a New Understanding of State Court Resistance. Emory Law Journal 51: 587-676.

Bayers, Peter. 2007. Larry Watson’s Montana 1948 and Euroamerican Representation of Native/Euroamerican History. Rocky Mountain Review 61(1): 35-50.

Bornman, Elirea. 2006. National Symbols and Nation Building in Post-Apartheid South Africa. International Journal of Intercultural Relations 30: 383-399.

Coles, Roberta. 2002. Manifest Destiny Adapted for 1990s War Discourse: Mission and Destiny Intertwined. Sociology of Religion 63(4): 403-426. 
Federal Register. Bureau of Indian Affairs. Department of the Interior. 14 June 2016. Volume 81, No 114. Indian Child Welfare Act Proceedings, Final Rule.

Graham, Lorie. 1998. “The Past Never Vanishes”: A Contextual Critique of the Existing Indian Family Doctrine. American Indian Law Review 23(1): 1-54.

Indian Adoption Project. http://pages.uoregon.edu/adoption/topics/IAP.html. Accessed 14 December 2016.

Indian Child Welfare Act. 1978.United States Code 25.

Kingsolver, Barbara. Pigs in Heaven. 2013. London: Faber and Faber Limited. (first published in 1993 by HarperCollins Publishers, Inc.).

Legislative History, House Report 95-1386, Indian Child Welfare Act of 1978

Metteer Lorillard, Christine.2005.The Role of Stories as an Impetus for Social Change, Stories that Make the Law Free: Literature as a Bridge Between the Law and the Culture in Which it Must Exist. Texas Wesleyan Law Review 12: 251-270.

Mississippi Band of Choctaw Indians v Holyfield. 490 U.S. 30 (1989).

Pratt, Julius. 1927.The Origin of "Manifest Destiny”. The American Historical Review 32(4):795-798.

Sargent, Sarah and Melling, Graham. 2012. Indigenous Self-Determination: The Root of State Resistance. Denning Law Journal 24: 117-137.

Schultermandl, Silvia. 2006.Motherhood and Mothering as Sites of Difference in Barbara Kingsolver's Pigs in Heaven (2006) Journal of the Association for Research on Mothering 8(1,2): 223-232.

Smith, Anthony. 1999. Myths and Memories of the Nation. Oxford: Oxford University Press/ Williams, Jr, Robert. 1990. The American Indian in Western Thought: The Discourses of Conquest. New York: Oxford University Press. 
